\title{
Retraining Needs of Technical Educators for the Implementation of the Junior Secondary School Basic Technology Programme In Nigeria
}

\author{
Atsumbe B. $\mathrm{N}^{1}$, Raymond $\mathrm{E}^{1}$, Idris A. $\mathrm{M}^{1}$, Mele E. $\mathrm{F}^{2}$. \\ ${ }^{I}$ Department of Industrial and Technology Education, Federal University of Technology,Minna, Niger state, \\ Nigeria \\ ${ }^{2}$ Department of Technology Education,Modibo Adama University of Technology, Yola, Adamawa State, Nigeria.
}

\begin{abstract}
Although there have been a general or public outcry about the inability of basic technology teachers to teach the subject effectively, little has been said on the areas of deficiency. Based on the forgoing this study was designed to determine the retraining needs of basic technology teachers. Three research questions guided the study. Head teachers of vocational subjects and basic technology teachers in secondary schools in Kogi state constitute the respondents. A 50 item questionnaire was used to collect the data. The data was analyzed using frequency counts and mean statistics. The data analysis revealed that basic technology teachers needs training and re - training in pedagogical skills and their background in various practical skills areas of basic technology are rickety and defective. Further analysis revealed that these teachers hardly manifest any affective work skills. Base on the finding some of the following recommendations were made. Immediate retraining for the current teachers of basic technology with emphasis in the areas of pedagogical and technical skills. Modification of the current NCE curriculum for training technical teachers and universities offering vocational education programmes should be used for the retraining during long vocations.
\end{abstract}

Key words: Retraining Needs, Technical Educators, Junior Secondary schools, Basic Technology.

\section{Introduction.}

Nigeria as a nation inherited a system of education from the colonial masters. This system of education was neither dynamic nor functional. It was neither meeting the needs of the society nor individuals. Infact Fafunwa (1990) observed that the purpose of that system of education was to produce catechist, singers, clerks, interpreters for the church and the government. As a result of the non-functional nature of this system, a new National policy on education emerged in 1977 revised, in 1981, 1994, and 2004 code named $6--3-3-4$ system of education (FGN, 2004). This system modified the post primary education curriculum to include prevocational subjects, which include Introductory Technology (Basic Technology). The components part of this subject include Technical Drawing, Metal Work, Woodwork, Electrical/Electronics, Auto Mechanics, Building technology, Basics of applied mechanics and Food Preservation. The national policy on education spells out the objectives of basic technology as:

i. Provide pre-vocational orientation for further training in technology.

ii. To provide basic technological literacy for everyday living; and

iii. To stimulate creativity. (FGN, 2004).

A national implementation committee was set up by the Federal government, to ensure effective takeoff of this programme, basic technology.

The committee observed that the teaching of this subject requires teachers who can demonstrate competencies desirable for intellectual growth of students, provide students with foundations for advance study in technology education and above the course ought to have provide activities in such a way that it will provide activities that will contribute to each student becoming an effective citizen capable of making sound economic judgment. According to Okeke (2008), the programme of study in the first year covers technical drawing, materials, workshop practice, energy, electricity, machines, introduction to maintenance and simple agriculture. Progressively; the scope is widened by the second and third years of the study to include metal, work, building technology etc. from the context of this subject and experiences these students are expected to acquire and be exposed to a vast array of content possibilities. It necessarily follows that teachers who actually implement the curriculum of ought to be well prepared. Furthermore, from the nature of the course, its teaching requires an interdisciplinary approach to the exclusion of subject's boundaries. Educators like Crews and Dickerson (1997) seriously noted that teacher quality is a strong predictor of student quality. More so, that it is widely acknowledged that no educational system can rise above the quality of its teachers". There is therefore great doubt as to the adequacy of teachers, in terms of quality, now handling the subject in our various secondary schools. The committees, FGN (2004) then observed that the present crops of teachers teaching the subject are grossly incompetent and incapable. Some recent studies carried out in the area of teacher quality for the Junior 
Secondary School basic technology in some states of the federation indicate negative disposition (Nduanya, etal, (2006), Unesco/UNDP, (2008), Okeke (2008). In a similar survey, Aina (2008) on technical teacher production noted that out of all the militating factors against the full implementation of the basic technology programme, the teacher quality factor ranks highest. The panel observed that almost all (majority) of the teachers employed to teach the subject cannot handle all the modules. Yet Olaitan (2002) strongly emphasized that a qualified basic technology educator for the junior secondary school should be able to teach basic courses in technical drawing, food storage and preservation, refrigeration, wood, metal, building and electrical/electronics technology.

The seriousness of the above problem is exacerbated by the fact that the entire nation is in doubt as to whether the objectives of the programme were being met. Thus, it has been established that the number of students who opt for the technology-based subjects at the Senior Secondary School level is not encouraging in terms of enrollment. Again the basic technology equipment and machines are lying waste not because they are not functional but because the available teachers can neither operate nor use them (Towe, 2005). Therefore, a teacher's knowledge of the above objectives of the course and the necessary experiences will go a long way to helping him select learning experiences capable of developing skills, abilities, understandings, habits, attitudes and appreciations among students, which they will need to meaningfully, enter and progress in employment. Where the teacher lacks such basic knowledge, his students are likely to become ill-equipped. This seems to be the situations in our school system today.

The importance of the teacher having both vocational skills through training and knowledge about teaching methodologies, students learning styles as well as being able to make effective use of both communication skills and instructional materials cannot be over emphasized. A bleak future, therefore, seems to await products of any programme which is faced with dearth of qualified manpower. This seems to be the fate of basic technology, hence the need for this study.

Certain competencies are considered pertinent for teachers of basic technology to enable them perform creditably. Such teachers should possess reasonable depths of knowledge in both the pedagogical skills and various areas of basic technology. In terms of apagogical skills, Crews and Dickerson have listed sixteen competences which are pertinent for professional teachers' preparation. They include:

1. Identifies learner's emotional, social, physical and intellectual needs;

2. Identifies and/or specifies instructional goals and objectives which are based on learners needs;

3. Designs instruction appropriate to goals and objectives which are based on learner's needs;

4. Implements instructions that is consistent with plan;

5. Designs and implements evaluation procedures which focus on leaner achievement and instructional effectiveness;

6. Demonstrates a repertoire of instructional models and teaching skills appropriate to specified objectives and to particular learners;

7. Promotes effective patterns of communication;

8. Uses resources appropriate to instructional objectives;

9. Integrates into instruction the cultural environments of students;

10. Modifies instruction on the basis of the learner's verbal and non verbal feed back during instruction;

11. Uses organizational and management skills to establish a maximally effective learning environment;

12. Identifies and reacts with sensitivity to the needs and feelings of self and others;

13. Exhibits openness and flexibility;

14. Works effectively as a member of a professional team;

15. Analyses professional effectiveness and continually strives to increase that effectiveness;

16. Designs and implements instructions which incorporates career education concepts.

With regards to knowledge in the various technical areas, the teacher should have mastery of both the various tasks and task elements in basic technology; such as include;

1. Understanding and appreciation of the need for technology;

2. Demonstrate the knowledge of career prospects and opportunities in technology;

3. Identification, classification, uses and processing of wood;

4. Identification, classification, production and heat treatment of metals;

5. Identification, uses and processing of natural engineering materials (clay, plastics, rubber and ceramic);

6. Demonstrate the knowledge of classification of hand tools;

7. Identification and uses of basic machine tools in the multipurpose workshop;

8. Knowledge and correct use of woodwork tools;

9. Knowledge and use of metal work tools and work holding devices;

10. Knowledge and correct use of drills and drilling machines in metal workshop;

11. Knowledge of workshop safety rules and regulations;

12. Demonstrate basic knowledge of geometry and technical drawing;

13. Identify and classify basic joints used in wood constructions; 
14. Knowledge of forms and sources of energy;

15. Knowledge of the inter-relationship between electricity and magnetism;

16. Demonstrate basic knowledge of applied mechanics, e.g. friction, motions, airflow mechanical advantage;

17. Knowledge of various types of foundations, walls, floors, doors and windows;

18. Knowledge of the various ways to maintain tools and equipment.

On the basis of the above listed requisite competencies, the following research questions were drawn to guide the study.

\section{Research Questions}

1. What are the pedagogical needs of Junior Secondary School, basic technology teachers?

2. What are the technical skills required by Junior Secondary School teachers of basic technology?

3. What are the affective works skills need of Junior Secondary School teachers of basic technology?

\section{Methodology.}

The study was a survey research involving 216 respondents, made up of 161 teachers of basic technology and 55 head teachers of various vocational education courses. The area of study is Kogi state of Nigeria. The respondents were asked to respond to statements seeking to find out their perceptions and knowledge regarding the pedagogical, technical and affective work skills required by teachers of basic technology. Questionnaire was the instrument employed to elicit the required information from the respondents. They were required to tick to what extent they require each of the competencies (pedagogical, technical and affective). A five point rating scale was used to determine the level at which competence is required.

Highly Required (HR) -5

Required (R) -4

Moderately Required (MR) -3

Less Required (LR) -2

Not Required (NR) -1

Using the lower limit of Required category (3.45) as the cut off point, any item with mean equal to or above 3.45 was regarded as accepted or required while items whose mean fall below 3.45 were regarded as rejected or not required. The research questions where answered using frequency counts, mean, and standard deviation. The instrument was validated for relevance and coverage by technical educator experts, after which necessary corrections were made. Cronback Alph was used to establish the reliability of the instrument and a reliability coefficient of 0.89 was obtained. Thus the instrument was considered appropriate for use by the researcher.

\section{Research Question 1}

What are the pedagogical competencies required by Junior Secondary School Teachers of basic Technology?

Table 1

Mean responses of Head Teachers of vocational education and Basic Technology Teachers on pedagogical competencies Required

\begin{tabular}{|c|c|c|c|c|c|c|}
\hline \multirow[b]{2}{*}{ S/No } & \multirow{2}{*}{\multicolumn{2}{|c|}{ Description of items }} & \multicolumn{3}{|c|}{$N_{1}=166$} & \multirow{2}{*}{$\begin{array}{l}\mathrm{N}_{2}=55 \\
\text { Remarks }\end{array}$} \\
\hline & & & $\mathbf{x}_{1}$ & $\mathbf{X}_{2}$ & $\mathbf{X}_{t}$ & \\
\hline 1. & $\begin{array}{l}\text { Identifies learner's emotional, and social } \\
\text { Physical and intellectual needs }\end{array}$ & 4.29 & 4.72 & 4.51 & Required & \\
\hline 2. & $\begin{array}{l}\text { Identifies and/or specifies instructional goals } \\
\text { and objectives which are based on learners needs }\end{array}$ & 4.09 & 4.49 & 4.29 & Required & \\
\hline 3. & $\begin{array}{l}\text { Designs instruction appropriate to goals and } \\
\text { objectives }\end{array}$ & 4.10 & 4.23 & 4.16 & Required & \\
\hline 4. & Implement instructions that are consistent with plan & 4.20 & 4.25 & 4.22 & Required & \\
\hline 5. & $\begin{array}{l}\text { Designs and implements evaluation procedure } \\
\text { which focus on learner achievement and } \\
\text { instructional effectiveness. }\end{array}$ & 3.69 & 4.14 & 3.91 & required & \\
\hline 6. & $\begin{array}{l}\text { Integrates into instruction the cultural environment } \\
\text { of students }\end{array}$ & 3.91 & 3.49 & 3.70 & Required & \\
\hline 7. & $\begin{array}{l}\text { Demonstrate a repertoire of instructional models } \\
\text { and teaching skills appropriate to specified } \\
\text { objectives and to particular learners. }\end{array}$ & 3.89 & 4.20 & 4.04 & Required & \\
\hline 8. & Promote effective pattern of communication 3.59 & 4.00 & 3.79 & Required & & \\
\hline 9. & Uses resources appropriate to instructional & 3.68 & 3.49 & 3.58 & Required & \\
\hline
\end{tabular}


Objectives.

10. Modifies instruction on the basis of learner's verbal $\begin{array}{llll}3.88 & 3.58 & 3.72 & \text { Required }\end{array}$ And non verbal feed back during instruction

11. Uses organizational and management skills to establish a maximally effective learning environment

12 . Identifies and reacts with sensitivity to the needs of and feelings of self and others.

13. Exhibits openness and flexibility

14. Works effectively as member of a professional team

15. Analyses professional effectiveness and continually strives to increase that effectiveness Designs and implements instruction which incorporates career education concepts.

4.00

Required

$\begin{array}{llll}3.69 & 3.60 & 3.64 & \text { Required }\end{array}$

$\begin{array}{llll}3.88 & 3.69 & 3.78 & \text { Required }\end{array}$

$\begin{array}{llll}3.59 & 3.61 & 3.60 & \text { Required }\end{array}$

$\begin{array}{llll}3.19 & 3.76 & 3.47 & \text { Required }\end{array}$

$\begin{array}{llll}3.60 & 3.25 & 3.42 & \text { Required }\end{array}$

Table 2

Mean Ratings of Head Teachers and Basic Technology Teachers on the technical skills required by Basic Technology Teachers

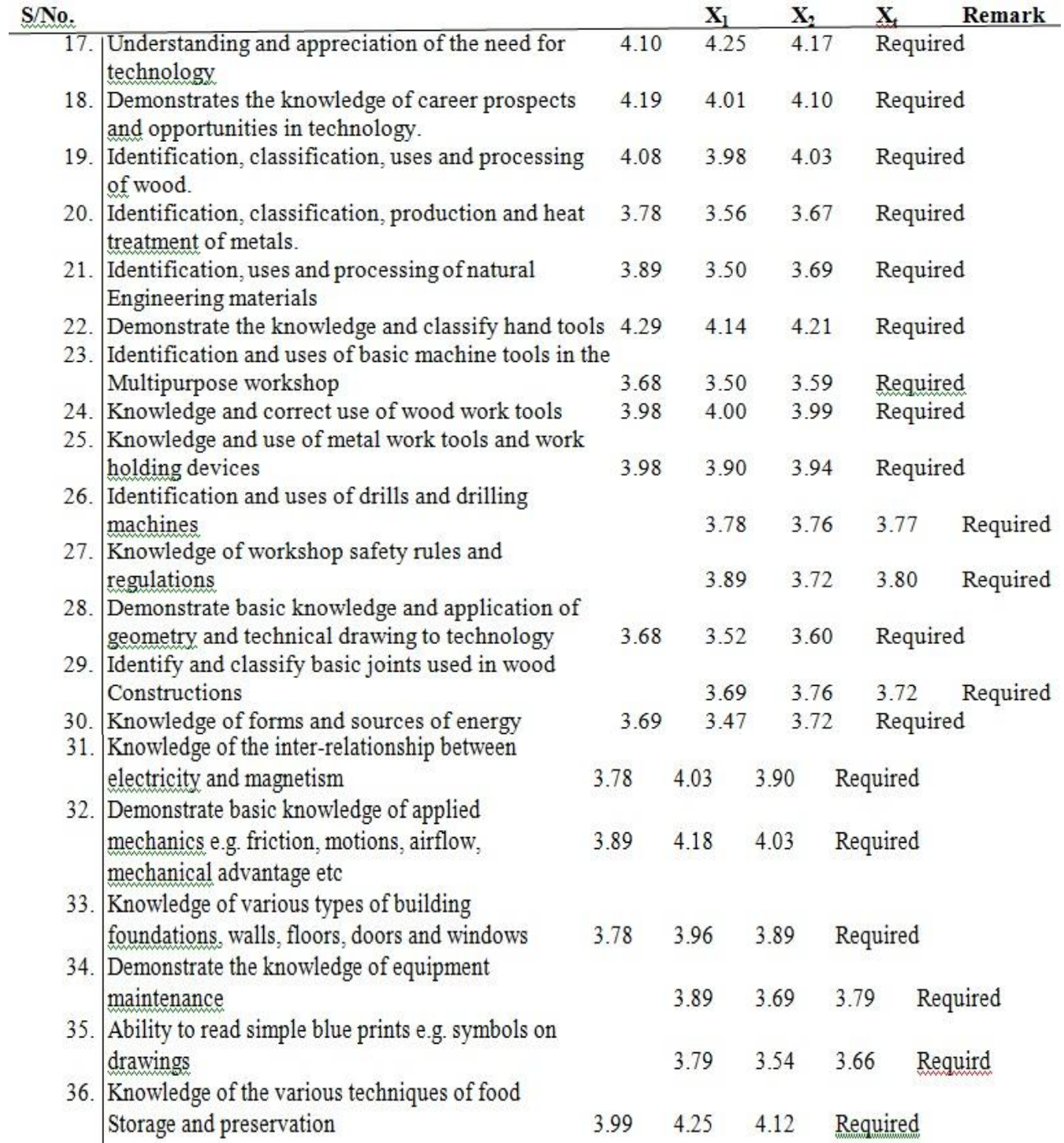




\section{Table 3}

Mean Ratings of Head Teachers and Basic Technology Teachers on the Affective work skills competencies required by basic technology teachers

\begin{tabular}{|c|c|c|c|c|c|c|}
\hline No. & Observing safety precaution when performing & & $\mathrm{x}_{1}$ & $\mathbf{X}_{2}$ & $x_{t}$ & Remarks \\
\hline & Specific task & & 3.59 & 3.50 & 3.54 & Required \\
\hline 2. & Develop positive work habit & & 4.29 & 4.23 & 4.26 & Required \\
\hline 3. & Ability to get along with co-workers & & 3.68 & 4.01 & 3.34 & Required \\
\hline 4. & Dependable when performing a given task & 3.90 & 3.80 & 3.87 & Require & \\
\hline 5. & Effective and prudent management of time and & & & 398 & & \\
\hline 6. & $\begin{array}{l}\text { Tesources } \\
\text { Appreciate the value of equipment and }\end{array}$ & & 3.58 & & 3.78 & Required \\
\hline & & & 3.98 & 3.72 & 3.84 & Required \\
\hline 7. & $\begin{array}{l}\text { Working without close supervision in the } \\
\text { workshop. } \\
\text { develop creativity or initiative and make }\end{array}$ & & 3.78 & 3.83 & 3.80 & Required \\
\hline & $\begin{array}{l}\text { develop creativity or initiative and make } \\
\text { suggestions for job improvement }\end{array}$ & 3.68 & 3.74 & 3.71 & Require & \\
\hline 9. & Ability to listen and carry out instructions & 3.98 & 4.03 & 4.00 & Require & \\
\hline 10. & d be emotionally & & 3.88 & 4.01 & & Required \\
\hline 11. & $\begin{array}{l}\text { Value time and punctual to work } \\
\text { Respect other people's opinion and loval to }\end{array}$ & 3.69 & 3.58 & 3.63 & Requir & \\
\hline 13. & $\begin{array}{l}\text { supervisors } \\
\text { Recognize the value of neatness and keep the }\end{array}$ & & 3.90 & 4.72 & 4.31 & Required \\
\hline 14. & $\begin{array}{l}\text { Workshop neat } \\
\text { Develop the habit of accuracy and efficiency }\end{array}$ & 4.06 & 4.21 & 4.14 & Require & \\
\hline & When working in the laborator & 3.70 & 3.61 & 3.65 & Reguire & \\
\hline 15. & To be honest and trust worthy & & 3.88 & 3.96 & 3.92 & Required \\
\hline $\begin{array}{c}16 . \\
17 .\end{array}$ & $\begin{array}{l}\text { Develop interest on the job } \\
\text { To be very hard working }\end{array}$ & 3.99 & 3.80 & 3.89 & Required & \\
\hline 18. & Develop positive maintenance culture in handling & & & & & \\
\hline & Tools and equipments & & 3.88 & 3.74 & 3.81 & quired \\
\hline
\end{tabular}

IV. Results.

Results from table 1 shows that all the pedagogical skills proposed where rated as required with mean ranging of between $3.47-4.29$. The Respondents unanimously agreed with all the items.

Table 2, that addressed basic technical skill competencies required by basic technology teachers were jointly accepted as required by the respondents with mean weightings of $4.21-3.59$.

Results and analysis of table 3 that addressed affective work skills need of basic technology teachers, shows that the respondents agreed with all the proposed affective work skills as required with very high mean of between $4.31-3.54$.

Summary of these analysis only suggest strongly that these teachers are ill - equipped professionally. Similar analysis was made in the case of basic technology skills. From the results the teachers presently engaged in basic technology teaching seem to grossly lack requisite skills and knowledge to teach the subject and seriously lack interpersonal skills. Consequent upon the results of tables 1,2, 3, discussion has been made.

\section{Discussions.}

The endorsement or acceptance of all these items in table one is not coming as a surprise. The acceptance of these items particularly the ones that deal with knowledge of career education. This because the knowledge of career is crucial to technical educators who should aspire to implement the concept in the classroom. According to Osula (2005) at the Junior Secondary Schools the teacher should be able to stimulate occupational interest and provide exploratory and pre - vocational experiences centered on a study of specific occupations and occupational clusters. According to Atsumbe (2003) an average basic technology teacher should be able to provide correct occupational information to the students. This is because career is concerned with the preparation of students for successful work life by improving the basis for their career choice and facilitates the learning of job skills.

Therefore, it is on this basis that Olaitan (2006), stressed that students should be guided through educational experiences to make decisions about participation in the world of work. Thus any technical education programme which neglects career education is deficient and will need a serious review. The present crop of basic technology teachers seems to grossly lack the capacity to impart this kind of knowledge.

Further analysis of table 1 shows other areas of serious concern include the teachers' knowledge of their professional responsibilities, utilization of organization and management skills, demonstrating a repertoire of 
appropriate instructional models and teaching skills, relating instructions to learner's cultural environment and identifying the variegated needs of learners as well as formulating objectives based on such needs. According to Okeke (1989), ninety - five percent (95\%) of these teachers have little or no background in education; they are those who migrated from engineering to pick teaching as a last resort in seeking employment.

But according to Ikwuni (2010), one of the major aims of teachers' education as contained in the National policy on Education, FGN (2004) is to provide teachers with the intellectual and professional background adequate for their assignments and make them adaptable to changing situations. Some of the teacher's basic assignment border on organizational and management skills, teaching skills, ability to understand your learners and carry them along successfully, and creating a conducive atmosphere that facilitates teaching and learning.

Table 2, addressed technical skills required by teachers of basic technology, the situation seemed further aggravated. Even though many of the teachers seem to show awareness of the need for technology, most of them lacked, disturbingly, the capacity to function in many areas of basic technology. Okeke (1989) further noted that other areas which require practical knowledge manifest a lot of deficiencies. A similar study by Atsumbe (2009) revealed that the current crop of basic technology teachers suffer lack of knowledge in several areas of basic technology, because the single straight jacket training they got in either wood work, metal work or building technology is not enough to qualify them to teach all aspects of the programme. Oranu (2002) stressed the fact that basic technology requires an integrated approach, since the syllabus is integrated in nature. He further emphasized that teacher of basic technology needs trainings that are inter-disciplinary in nature. It is unlike the former curriculum that which stress training in a specific area such as metal work, wood work, basic electronics, building etc. It in the light of the above that Okeke (1989) suggested that there is need to modify the curriculum of the current Nigeria Certificate of Education (Technical) to Basic Technology as a distinct course of study to be combined with science subject - Basic technology/chemistry, Basic technology/mathematics, or Basic technology/physics, etc. with such broader options, in addition to technical education subjects, it is hoped that these teachers will have seriously improved on their knowledge of basic technology course areas.

Table 3 addressed affective work skills which are sometimes known as non technical competencies or socio-psychological factors of work. The two groups of respondents rated all the items in this cluster as required and a critical need of basic technology teachers. Their acceptance of these non technical competencies is not coming as a surprise, because according to Miller and Usoro (1999) developing desirable work attitudes is imperative for success in the world of work. Okoro (2005) observed in a similar research that poor attitudes and lack of work related interpersonal skills are the reasons why young workers loose their jobs. Kimbell and Vineyard (2007) further opined that affective work skills are more important for job survival than cognitive or psychomotor skills. The findings of this cluster of items are in agreement with the work of Anyakoha (1990) who noted that punctuality to work, honesty, use of time to the best advantage, thoroughness, prudence in the use of materials and correct inter-personal relationship with colleagues, subordinates and those in authority are examples all closely related to profit - a key to successful employment. She said these set of sociopsychological factors of work leads to higher productivity or good job performances. In an education related research Atsumbe (2002) discovered that environments where teachers practice or manifest correct affective work skills, learners are psychologically balanced, have high confidence in the teacher and in themselves, rate of absorption of materials taught are faster and seems to be able to work without close supervision. He said what is called classroom or subject phobia is completely removed. The practice and application of non-technical competencies are most needed in vocational education related programmes, this because learner needs self confidence, positive work habits, complying with safety rules and being constantly prudent in the use of time and consumables.

\section{Conclusion}

Consequent on the above revelation, the following implications emerge. Basic technology teachers require training and re-training in pedagogical skills to enable them put their professional responsibilities into practice. The background of these teachers in basic technology was found to be rickety and completely defective. This finding supported an earlier report that several of the basic technology teachers in many part of Nigeria are actually not qualified to teach the subject. Though several Nigeria curricular are silent about affective skills, it was also established that teachers of basic technology who are actually vocational educator have great need of those non-technical competencies if the learners are to graduate as competent craftsmen, technicians, technologist etc. 


\section{Recommendations}

1. Teachers of basic technology have great need for training and retraining to equip them both in pedagogical, technical and affective work skills required for effective functioning as basic technology educators.

2. Nigerian Universities offering courses in vocational education could play a vital role in the retraining exercises especially during long vacations.

3. There is an urgent need for curriculum modification and in-service training education.

4. The current practices where students are trained in main single subject area have to stop. Rather am suggesting that basic technology should be offered as a distinct course or at best it could be combined with science subject - Basic technology/mathematics; basic technology/physics; basic technology/chemistry etc.

5. A systematic programme for a period of three years, utilizing the vacation periods, for serving teachers, will go along way to equipping such teachers qualitatively.

6. Attendance by all the teachers in this category should be made mandatory.

7. Emphasis in retraining should be in the areas of technical skills in the deficient areas as well as requisite pedagogical skills.

\section{References.}

[1.] Aina, O .C. (2008). Technical and Vocational Training as a strategy for Technical Development.Journal of Teacher Education of Nigeria. 1 (1), $129-136$

[2.] Anyankoha, E. A (1990), Assessment of work ethics of vocational education graduates in Secondary schools in Anambra states. Journal vocational education. 2 (2), $57-65$.

[3.] Atsumbe, B. N (2009), Affective work skill needs of Engineering and Technology students inUniversities of North central states of Nigeria. Journal of pure and applied science 1 (1)100 -119.

[4.] Atsumbe, B. N (2002), Towards Effective Teaching of introductory technology in the JSS.(problems \& solutions). A paper presented at the $1^{\text {st }}$ National conference of Nigerian Association of Teachers of Technology, Niger state chapter $15^{\text {th }}-18^{\text {th }}$, June.

[5.] Crews, W. J. \& Dickerson, Z. S (1997). Curriculum Development in Education for Business,National Business Education Association, Reston: Virginia 22091, pg77.

[6.] Federal Republic of Nigeria, (2004). National policy on Education. Federal Ministry of Education, printing division Lagos.

[7.] Ikwni, G. C. (2010). Educational Administrators Evaluation of the performance of Technolog Education Teachers in Secondary schools in Delta state. Unpublished M. Tech thesis. Dept Of Industrial \& Technology Education, Federal University if Technology, Minna.

[8.] Kimbell, R.S \& Vineyard, F. O. (2007), A study of supervisor and Employer perceptions of Work attitudes in information age manufacturing. Journal of vocational Education Research. 28 (3), $185-215$.

[9.] Nduanya, M. O. (2996), Report submitted to the Anambra state Ministry of Education on Rationalization of Teacher Education programmes. Pg7, $30-41$.

[10.] Okeke, C. C. (2008), Provision for the pre - vocational subjects at the JSS level in Anambra State. Problem and strategies. In Ehiametalor, E.T. (ed). Implemtation of the National Policy on Education, NERA. 69 -74.

[11.] Okeke. C.C. (1989), Curriculum Needs of Technical Educators for the implementation of the JSS Introductory technology programme. In Ehiametalor, E.T.(ed). Implementation of the National policy on Education, NERA. 228 - 235.

[12.] Okoro, M. O. (2005), Vocational and Technical Education. Principle and Methods . pacific pres Ltd. Urowalu - obosi.

[13.] Olaitan, S. O. (2006), Review of Technical and Vocational Education in Nigerian Schools. A Paper presented at the $10^{\text {th }}$ anniversary of NBTE Kaduna. $12^{\text {th }}-14^{\text {th }}$ October

[14.] Olaitan, S. O. (2002), Issues and problems in vocational and technical education teacherPreparation. A paper presented at the National curriculum review conference, Kaduna. $2^{\text {nd }}-6^{\text {th }}$. October.

[15.] Oranu, R. N. (2002), Vocational Education and Manpower Development. A paper presented At the $6^{\text {th }}$ annual conference of Nigerian Vocational Association. FEC(T) Umunze. $6^{\text {th }}-8^{\text {th }}$ October.

[16.] Osuala, E.C. (2005), Foundation of Vocational Education. Chicago: American Technical society.

[17.] Towe, E. C. (2005), Instructional Techniques in Vocational Education. American Technical Publishers Inc.

[18.] Usoro, L. O. (1990), Effective Teaching in Technology Education as a Research Activity. Journal of tTechnical Education Review. $2(2), 3-10$. 